\title{
Understanding the molecular diversity of GABAergic synapses
}

\author{
Marco Sassoè-Pognetto ${ }^{1,2}$, Elena Frola ${ }^{1,2}$, Giulia Pregno ${ }^{1,2}$, Federica Briatore ${ }^{1,2}$ and Annarita Patrizi ${ }^{1,2 \dagger}$ \\ ' Department of Anatomy, Pharmacology and Forensic Medicine, University of Turin, Torino, Italy \\ ${ }^{2}$ National Institute of Neuroscience, Torino, Italy
}

Edited by:

Enrico Cherubini, International School for Advanced Studies, Italy

Reviewed by:

William Wisden, Imperial College, UK Paola Zacchi, International School for Advanced Studies, Italy

*Correspondence:

Marco Sassoè-Pognetto, Dipartimento di Anatomia,

Farmacologia e Medicina legale, University of Turin, C.so Massimo d'Azeglio 52, 10126 Torino, Italy. e-mail: marco.sassoe@unito.it

${ }^{t}$ Present address:

Annarita Patrizi, F.M. Kirby

Neurobiology Center, Children's Hospital, Harvard Medical School, Boston, MA, USA.
GABAergic synapses exhibit a high degree of subcellular and molecular specialization, which contrasts with their apparent simplicity in ultrastructural appearance. Indeed, when observed in the electron microscope, GABAergic synapses fit in the symmetric, or Gray's type II category, being characterized by a relatively simple postsynaptic specialization. The inhibitory postsynaptic density cannot be readily isolated, and progress in understanding its molecular composition has lagged behind that of excitatory synapses. However, recent studies have brought significant progress in the identification of new synaptic proteins, revealing an unexpected complexity in the molecular machinery that regulates GABAergic synaptogenesis. In this article, we provide an overview of the molecular diversity of GABAergic synapses, and we consider how synapse specificity may be encoded by selective trans-synaptic interactions between pre- and postsynaptic adhesion molecules and secreted factors that reside in the synaptic cleft. We also discuss the importance of developing cataloguing tools that could be used to decipher the molecular diversity of synapses and to predict alterations of inhibitory transmission in the course of neurological diseases.

Keywords: GABAergic synapse, GABA ${ }_{A}$ receptor, gephyrin, dystroglycan, neuroligin, neurexin, synapse specificity

\section{INTRODUCTION}

One of the most striking aspects of inhibitory synaptic circuits is the remarkable diversity of GABAergic systems. GABAergic interneurons occur in many different subtypes, that play exquisitely precise functions in neural networks (Markram et al., 2004). Each type of interneuron is highly selective, making synapses with particular populations of target cells and only with specific subcellular compartments (Huang et al., 2007). Moreover, the diversity of GABAergic interneurons matches a corresponding multiplicity of synaptic and extrasynaptic $G_{A B A}$ receptor $\left(G_{A B A} R\right)$ subtypes, that support neural circuit operations under an extensive range of behavior-dependent brain states (Monyer and Markram, 2004; Freund and Katona, 2007; Klausberger and Somogyi, 2008; Olsen and Sieghart, 2009). For example, in hippocampal and cortical circuits, basket cells containing either parvalbumin (PV) or cholecystokinin (CCK) target the cell body of pyramidal cells at synapses containing mainly $\alpha 1 \beta 2 / 3 \gamma 2 \mathrm{GABA}_{\mathrm{A}} \mathrm{Rs}$, which display fast kinetics of deactivation, or $\alpha 2 \beta 2 / 3 \gamma 2 \mathrm{GABA}_{\mathrm{A}} \mathrm{Rs}$, which have slower kinetics compared to receptors containing the $\alpha 1$ subunit (Klausberger et al., 2002; Klausberger and Somogyi, 2008). While PV-basket cells appear to control the temporal coordination of principal neurons and network oscillations, CCK-positive interneurons modulate synchronous activities by integrating subcortical and local modulatory signals (Freund and Katona, 2007; Sohal et al., 2009; Thomson and Jovanovic, 2010). Notably, these differences can be extended to the level of pathology, as the two types of $\mathrm{GABA}_{\mathrm{A}}$ Rs appear to be implicated in different types of neurological and psychiatric disorders (Lewis et al., 2005; Freund and Katona, 2007). Similarly, genetic manipulations of individual
$\mathrm{GABA}_{\mathrm{A}} \mathrm{R}$ subunits in mice produce selective alterations in behavior, reinforcing the idea that specific neuronal networks characterized by respective $\mathrm{GABA}_{\mathrm{A}} \mathrm{R}$ subtypes are involved in the regulation of defined behavioral patterns (McKernan et al., 2000; Möhler, 2006, 2007; Whiting, 2006).

This extraordinary diversity contrasts with the apparent simplicity in the ultrastructural appearance of GABAergic synapses. When observed in the electron microscope, GABAergic synapses fit in the symmetric, or Gray's type II category (Gray, 1959; Colonnier, 1968; Peters and Palay, 1996). These synapses are characterized by a thin postsynaptic density (PSD), similar in size to the presynaptic active zone. In contrast, glutamatergic synapses belong to the asymmetric, or Gray's type I group, which is distinguished by a prominent PSD. Asymmetric synapses also show a conspicuous electron dense material in the synaptic cleft, which is less obvious in symmetric synapses. Not surprisingly, the morphological differences between type I and type II synapses are proportional to their molecular complexity. Proteomic studies of the excitatory PSD have revealed a number of proteins greater than 1000 (Collins et al., 2005; Bayés et al., 2011), which exceeds by two orders of magnitude the number of molecules that have been found in the inhibitory PSD (Lüscher and Keller, 2004; Charych et al., 2009). It would be hazardous, however, to conclude that all GABAergic synapses share the same basic molecules and mechanisms to sustain their exquisite specificity. In this essay, we review recent work that points to a remarkable heterogeneity of the molecular machinery that regulates GABAergic synaptogenesis in vivo and we provide a personal view of the mechanisms that may underlie synapse specificity during the development of neural circuits. 
Understanding these mechanisms is of interest for both basic and clinical neuroscience, as disruption of inhibitory synapse development is now regarded as a major cause of brain disease (Lewis et al., 2005; Südhof, 2008; Charych et al., 2009). A detailed description of the molecular organization of GABAergic synapses falls outside the scope of this paper and can be found in other excellent review articles (Lüscher and Keller, 2004; Tretter and Moss, 2008). Here we rather focus on the evidence that the diversity of GABAergic synapses may be generated by the interplay of multiple molecular mechanisms with partially overlapping functions. We also discuss the importance of a classification scheme that could be used to identify distinct types of synapses based on the differential expression of groups of interacting proteins.

\section{POSTSYNAPTIC SCAFFOLDS OF INHIBITORY SYNAPSES}

One of the main achievements in the field of synapse research has been the characterization of the molecular components of the PSD. Molecular investigations of glutamatergic synapses have shown that the PSD is a specialized microdomain characterized by core scaffolding proteins, such as PSD-95, that link glutamate receptors to the subsynaptic cytoskeleton and also interact with different types of regulatory proteins and with cell adhesion molecules via specific PDZ domains (Kennedy, 1997; Ziff, 1997; O'Brien et al., 1998; Garner et al., 2000; Kim and Sheng, 2004; Boeckers, 2006). Importantly, there is increasing evidence that proteinprotein interactions within the PSD are not static and that dynamic modulation of the PSD provides a mechanism for the regulation of synaptic plasticity (Scannevin and Huganir, 2000; Kim et al., 2007; Steiner et al., 2008). The inhibitory PSD cannot be readily isolated, and progress in understanding its molecular composition has lagged behind that of excitatory synapses. The multi-domain, $93 \mathrm{kDa}$ protein gephyrin has emerged as a major scaffolding molecule of the inhibitory PSD (Kneussel and Betz, 2000; Fritschy et al., 2008). Here we briefly summarize the proposed functions of gephyrin and we describe other scaffolding molecules that may contribute to assemble postsynaptic specializations in at least some subtypes of inhibitory synapses.

\section{GEPHYRIN}

Gephyrin was originally copurified with the glycine receptor (GlyR; Pfeiffer et al., 1982), and was later found also at postsynaptic sites of GABAergic synapses (Sassoè-Pognetto et al., 1995; Sassoè-Pognetto and Fritschy, 2000). This molecule lacks PDZ domains, but can form aggregates by spontaneous oligomerization, although the precise mechanisms by which gephyrin forms postsynaptic scaffolds is still unresolved (for review, see Fritschy et al., 2008). Gephyrin binds a cytoplasmic loop of the GlyR $\beta$ subunit (Meyer et al., 1995), and is essential for postsynaptic clustering of GlyRs (Kirsch et al., 1993; Feng et al., 1998). This scaffold protein also contributes to stabilize postsynaptic $\mathrm{GABA}_{\mathrm{A}} \mathrm{Rs}$, as its knockdown in cultured neurons causes a disruption of $\mathrm{GABA}_{\mathrm{A}} \mathrm{R}$ clusters (Essrich et al., 1998; Yu et al., 2007). Similarly, knockout of the gephyrin gene in mice results in an extensive loss of postsynaptic GABA $_{\mathrm{A}} \mathrm{R}$ aggregates (Kneussel et al., 1999, 2001; Fischer et al., 2000; Lévi et al., 2004).

The precise mechanisms by which gephyrin clusters $\mathrm{GABA}_{\mathrm{A}} \mathrm{Rs}$ are poorly understood, although there is evidence that this molecule restrains the lateral mobility of the receptors in the plasma membrane (Jacob et al., 2005; Thomas et al., 2005). Most likely, this function involves interactions with the cytoskeleton, as gephyrin binds with high affinity polymerized tubulin (Kirsch et al., 1991; Kirsch and Betz, 1995) and serves as an adaptor for regulators of microfilament dynamics (Mammoto et al., 1998; Giesemann et al., 2003; Bausen et al., 2006). Interestingly, the clustering of gephyrin and $\mathrm{GABA}_{\mathrm{A}} \mathrm{Rs}$ are to some extent mutually dependent on each other, since synaptic gephyrin clusters are disrupted after deletion of $\mathrm{GABA}_{\mathrm{A}}$ Rs (Essrich et al., 1998; Schweizer et al., 2003; Li et al., 2005; Kralic et al., 2006; Studer et al., 2006). Alldred et al. (2005) have identified the fourth transmembrane domain of the $\mathrm{GABA}_{\mathrm{A}} \mathrm{R} \gamma 2$ subunit as essential to mediate postsynaptic clustering of $\mathrm{GABA}_{\mathrm{A}} \mathrm{Rs}$, whereas the major $\gamma 2$ cytoplasmic loop is required for recruitment of gephyrin to $G A B A_{A} R$ clusters. Direct interactions between gephyrin and the $\mathrm{GABA}_{\mathrm{A}} \mathrm{R} \alpha 2$ and $\alpha 3$ subunits have emerged only recently (Tretter and Moss, 2008; Saiepour et al., 2010). The binding of gephyrin to the $\alpha$ subunits appears to be detergent sensitive, which may explain why it has been remarkably difficult to reveal these interactions using biochemical approaches. However, whether gephyrin binding to $\mathrm{GABA}_{\mathrm{A}}$ Rs involves multiple interactions with distinct $\alpha$ and $\gamma$ subunits is presently unclear. The relevance of the numerous gephyrin isoforms generated by alternative splicing is also not understood (Paarmann et al., 2006; Fritschy et al., 2008). Moreover, gephyrin function may depend on post-translational modifications. Indeed, recent studies indicate that phosphorylation of gephyrin at specific residues contributes to regulate the anchoring of GlyRs and $\mathrm{GABA}_{\mathrm{A}} \mathrm{Rs}$ at postsynaptic sites (Zita et al., 2007; Charrier et al., 2010; Tyagarajan et al., 2011).

A still unresolved issue is whether gephyrin contributes equally to the clustering of all major subtypes of synaptic $G_{A B A}$ Rs (that is receptors that are highly concentrated in the postsynaptic membrane and mediate phasic inhibition). Extensive experimental evidence indicates that receptors containing a $\gamma 2$ subunit in association with two $\alpha$ and two $\beta$ subunits $(\alpha 1 \beta 2 / 3 \gamma 2, \alpha 2 \beta 2 / 3 \gamma 2$, and $\alpha 3 \beta 2 / 3 \gamma 2$ ) are the predominant types of synaptic $\mathrm{GABA}_{\mathrm{A}} \mathrm{Rs}$ (for review, see Lüscher and Keller, 2004; Farrant and Nusser, 2005). The analysis of spinal cord sections, retina organotypic cultures, and cultured hippocampal neurons derived from gephyrin knockout mice lead to the idea that gephyrin mediates the postsynaptic accumulation of $\mathrm{GABA}_{\mathrm{A}}$ Rs containing the $\alpha 2$ or the $\alpha 3$ subunit, and suggested the existence of additional clustering mechanisms (Fischer et al., 2000; Kneussel et al., 2001; Lévi et al., 2004). However, in the brain gephyrin colocalizes with all major types of postsynaptic $\mathrm{GABA}_{\mathrm{A}}$ Rs containing either the $\alpha 1, \alpha 2$, or $\alpha 3$ subunit (Sassoè-Pognetto et al., 2000), indicating that its function is not restricted to $\alpha 2$ and $\alpha 3$-containing synapses. Because gephyrin knockout mice die at birth (Feng et al., 1998), a better appreciation of gephyrin function at distinct types of GABAergic synapses may derive from the study of mouse models with conditional deletion of this protein in selected populations of neurons characterized by the expression of distinct $\mathrm{GABA}_{\mathrm{A}} \mathrm{R}$ subtypes. The complex situation regarding the role of gephyrin in the clustering of different $\mathrm{GABA}_{\mathrm{A}}$ Rs may also be explained by redundancy between multiple clustering factors with partially overlapping synaptic expression profiles (see below). 


\section{THE DYSTROPHIN-GLYCOPROTEIN COMPLEX}

Another postsynaptic scaffold that is present in some GABAergic synapses is dystrophin. This protein belongs to the dystrophinglycoprotein complex (DGC), a large, membrane-spanning protein complex that links the cytoskeleton to the extracellular matrix (Ervasti and Campbell, 1991; Blake and Kröger, 2000; Waite et al., 2009). Dystrophin is derived from a large gene with at least seven internal promoters that enable the expression of several distinct isoforms (for review see Perronnet and Vaillend, 2010). Interestingly, the full-length (Dp427) isoform is derived from three independent promoters with differential expression in muscle, forebrain, and cerebellar Purkinje cells. The $\mathrm{N}$-terminal domain of dystrophin binds to filamentous actin, whereas the C-terminal domain interacts with dystrobrevins $(\alpha$ and $\beta$ ) and syntrophins ( $\alpha, \beta 1-2, \gamma 1-2)$, which are also cytoplasmic constituents of the DGC. Several dystrobrevin-binding elements have been identified, including dysbindin, a protein that has been associated with schizophrenia (Benson et al., 2001; Talbot et al., 2009). However, immunohistochemical analyses suggest that dysbindin is not enriched at GABAergic synapses (unpublished observations). Syntrophins are adaptor proteins each containing a PDZ domain and two pleckstrin homology $(\mathrm{PH})$ domains mediating interactions with several other proteins, including kinases, ion and water channels, and nNOS (Waite et al., 2009).
Syntrophin colocalizes with $\mathrm{GABA}_{\mathrm{A}} \mathrm{Rs}$ in cultured hippocampal neurons (Brünig et al., 2002), however the synaptic localization of endogenous syntrophins in unknown. Of particular interest is the fact that the $\gamma 2$-syntrophin isoform has been reported to interact with the PDZ binding motif of the adhesion molecules neuroligin 3 and neuroligin 4 (Yamakawa et al., 2007), which are present at inhibitory synapses (see below). It is therefore possible that interactions between syntrophins and neuroligins may help organize postsynaptic scaffolds at inhibitory synapses (Figure 1).

A core component of the DGC is dystroglycan, which is composed of an extracellular $\alpha$ subunit and a transmembrane $\beta$ subunit, derived by proteolytic cleavage from a single precursor protein (Ibraghimov-Beskrovnaya et al., 1992). The $\beta$ dystroglycan subunit contains a single transmembrane domain and its cytoplasmic tail binds dystrophin, whereas $\alpha$-dystroglycan is a secreted glycoprotein that binds to LNS (laminin G, neurexins, and sex hormone-binding globulin)-domain-containing proteins, such as laminin, perlecan, agrin, neurexin, and pikachurin (Bowe et al., 1994; Gee et al., 1994; Talts et al., 1999; Sugita et al., 2001; Sato et al., 2008). The fact that $\alpha$-dystroglycan binds neurexin is particularly intriguing, as it suggests that the DGC may mediate trans-synaptic interactions between pre- and postsynaptic specializations.

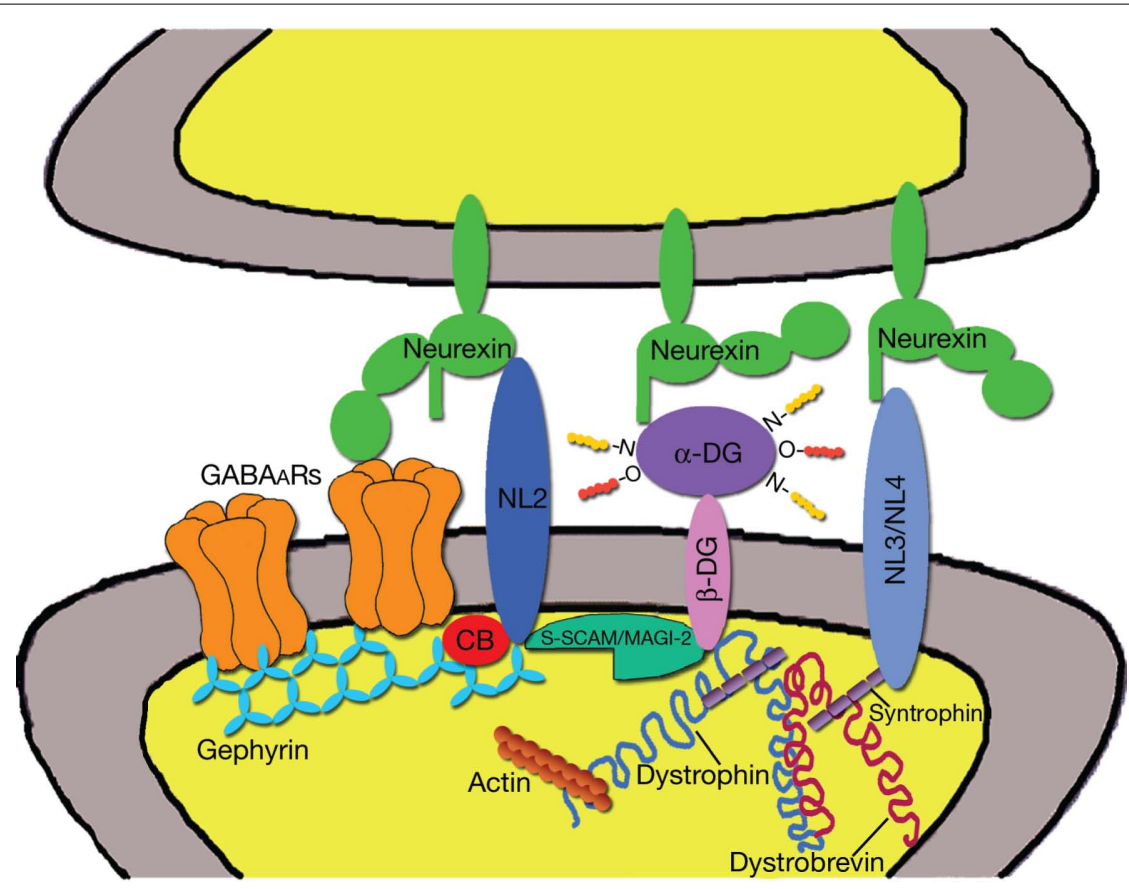

FIGURE 1 | Postsynaptic scaffolds and adhesion molecules of GABAergic synapses. The diagram is based on reported molecular interactions (see text), some of which remain to be confirmed in vivo. Gephyrin, S-SCAM/MAGI-2, and dystrophin are shown in the same postsynaptic specialization, although dystrophin is present in only a subset of GABAergic synapses and the in vivo distribution of S-SCAM/MAGI-2 has not been characterized. Gephyrin trimers are believed to aggregate into a

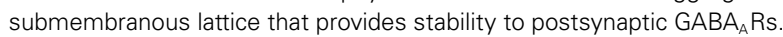
Gephyrin also binds collybistin (CB) and neuroligin 2 (NL2), that has been proposed to function as a specific activator of collybistin. Cytoskeletal proteins associated with gephyrin, such as MenaNASP and microtubules, are not shown. Neuroligin 2 bridges the synaptic cleft and binds to neurexins on the presynaptic terminal. Reported interactions between neurexins and $\mathrm{GABA}_{A} \mathrm{Rs}$ are also indicated. Neurexins may also interact with $\alpha$-dystroglycan $(\alpha-D G)$, thus establishing a link with the dystrophin-glycoprotein complex (DGC). One component of the DGC, syntrophin, has been reported to bind neuroligin 3 and neuroligin 4. Finally, there is evidence that S-SCAM/MAGI-2 may establish a link between neuroligin 2 and the DGC by interacting with the intracellular domain of $\beta$-dystroglycan ( $\beta$-DG). 
Immunohistochemical analyses have shown that the DGC is present in a subset of GABAergic synapses, specifically in cerebellar Purkinje cells and in forebrain pyramidal neurons (Knuesel et al., 1999; Sekiguchi et al., 2009; Briatore et al., 2010). Interestingly, both in vitro and in vivo analyses have shown that the synaptic localization of dystrophin and dystroglycan are independent of $\mathrm{GABA}_{\mathrm{A}}$ Rs and gephyrin, suggesting that the DGC has the capacity to self-assemble at postsynaptic sites (Brünig et al., 2002; Lévi et al., 2002; Patrizi et al., 2008a). The studies that have investigated the function of the DGC at GABAergic synapses have generated partially conflicting results. Deletion of dystroglycan in cultured hippocampal neurons caused a loss of postsynaptic dystrophin, but did not affect the localization of gephyrin and $\mathrm{GABA}_{\mathrm{A}}$ Rs (Lévi et al., 2002). In contrast, in vivo analyses of $m d x$ mice, that lack the full-length version of dystrophin, revealed a selective deficit in the synaptic clustering of $\mathrm{GABA}_{\mathrm{A}} \mathrm{Rs}$, but not gephyrin, in cerebellum, hippocampus, and amygdala (Knuesel et al., 1999; Sekiguchi et al., 2009; Vaillend et al., 2010). Similar results have been reported in the cerebellum of double knockout mice lacking both $\alpha$ and $\beta$ dystrobrevins (Grady et al., 2006). The selective loss of $\mathrm{GABA}_{\mathrm{A}} \mathrm{R}$ clusters, but not gephyrin clusters in $m d x$ mice is surprising, also considering that deletion of $\mathrm{GABA}_{\mathrm{A}}$ Rs from Purkinje cells causes a severe defect in the clustering of gephyrin (Kralic et al., 2006) without affecting dystrophin and dystroglycan (Patrizi et al., 2008a). However, there is extensive electrophysiological evidence indicating that an intact DGC is required for normal GABAergic inhibition (Anderson et al., 2003; Kueh et al., 2008; Sekiguchi et al., 2009). In short, the available data indicate that the DGC is involved in modulating synaptic function in a subset of GABAergic synapses. However, the precise organization of the synaptic DGC and the specific contribution of its molecular constituents require further investigations.

\section{S-SCAM/MAGI-2}

According to a recent study, the synaptic scaffolding molecule (S-SCAM)/membrane-associated guanylate kinase with inverted organization (MAGI)-2 localizes at inhibitory synapses in rat primary hippocampal neurons (Sumita et al., 2007). This is surprising, because S-SCAM/MAGI-2 has a molecular organization similar to PSD-95, harboring multiple PDZ domains, a guanylate kinase, and two WW domains. S-SCAM/MAGI-2 is also present at glutamatergic synapses, where it interacts with NMDA receptors, neuroligin 1 , and $\beta$-catenin (Hirao et al., 1998; Iida et al., 2004). At GABAergic synapses, it has been reported that S-SCAM/MAGI-2 can interact with $\beta$-dystroglycan and neuroligin 2, suggesting that this scaffold molecule may provide a link between the DGC and the neurexin-neuroligin adhesion system (Sumita et al., 2007). Thus it appears that S-SCAM/MAGI-2 and syntrophins may mediate selective interactions between the DGC and, respectively, neuroligin 2 and neuroligins 3 and 4 (Figure 1). Research on S-SCAM/MAGI-2 is still at its beginnings, but it may lead to the discovery of new mechanisms underlying the assembly of the inhibitory PSD. It will be important to characterize the spatio-temporal profile of S-SCAM/MAGI-2 expression in relation to the other molecular constituents of GABAergic postsynapses. In addition, it will be of primary interest to investigate the possible redundancy of trans-synaptic signals mediated by the DGC and the neurexin-neuroligin adhesion system. More in general, in vivo analyses are needed to get a clear picture of the endogenous distributions of these different scaffolding systems and to help dissecting their specific roles in different populations of synapses.

\section{VARIABILITY IN THE MECHANISMS THAT REGULATE THE POSTSYNAPTIC ACCUMULATION OF GEPHYRIN}

While gephyrin is expressed almost ubiquitously at inhibitory synapses, recent studies have evidenced an unexpected variability in the mechanisms that control its synaptic localization. For example, in cerebellar Purkinje cells gephyrin is expressed initially at all GABAergic synapses, however during postnatal development gephyrin clusters disappear from perisomatic synapses and remain exclusively at axodendritic contacts (Viltono et al., 2008). While the reasons for this differential regulation are unclear, the loss of gephyrin is mirrored by a structural reorganization of perisomatic synapses, consisting in a reduction in the size of $\mathrm{GABA}_{\mathrm{A}} \mathrm{R}$ clusters and in the length of synaptic appositions.

One protein implicated in the recruitment of gephyrin to postsynaptic specializations is the GEF (guanine nucleotide exchange factor) collybistin, that was identified as a gephyrin-binding protein in a two-hybrid screening (Kins et al., 2000). Collybistin, like other GEFs, is characterized by an N-terminal src homology 3 (SH3) domain, a catalytic tandem Dbl homology (DH) domain and a $\mathrm{PH}$ domain. It is believed that collybistin participates in the membrane targeting of gephyrin by binding membrane lipids through its PH domain (Harvey et al., 2004; Reddy-Alla et al., 2010). Different collybistin isoforms (CB1-3) have been identified, which are created by alternative splicing of exons encoding the $\mathrm{SH} 3$ domain and three alternate C termini (Kins et al., 2000; Harvey et al., 2004). Interestingly, expression studies have shown that the $\mathrm{SH} 3$ domain negatively regulates collybistin function (Kins et al., 2000; Harvey et al., 2004). However, most endogenous collybistin isoforms harbor this region, suggesting that collybistin activity requires protein-protein interactions at the $\mathrm{SH} 3$ domain (Kins et al., 2000; Harvey et al., 2004). Indeed, recent investigations have shown that the synaptic adhesion molecules neuroligin 2 and neuroligin 4 can bind to and activate collybistin by relieving the SH3-mediated inhibition (Poulopoulos et al., 2009; Hoon et al., 2011). In addition, all neuroligin isoforms have in their cytoplasmic domain a conserved gephyrin-binding motif that contributes to recruit gephyrin to synapses. It has been proposed that by interacting with gephyrin and collybistin neuroligin 2 can act as a nucleation site for the formation of postsynaptic gephyrin scaffolds that recruit $\mathrm{GABA}_{\mathrm{A}}$ Rs at postsynaptic sites (Poulopoulos et al., 2009). On the other hand, knockout of neuroligin 2 has only a relatively small effect on the clustering of gephyrin and $G_{A B A}$ Rs, specifically at perisomatic synapses of hippocampal neurons (Poulopoulos et al., 2009). In contrast, deletion of collybistin or $\mathrm{GABA}_{\mathrm{A}}$ Rs causes an extensive loss of gephyrin clusters (Essrich et al., 1998; Li et al., 2005; Kralic et al., 2006; Studer et al., 2006; Papadopoulos et al., 2007; Patrizi et al., 2008a). These observations question the importance of neuroligin 2 as a major physiological clustering factor for gephyrin and collybistin and suggest that there could be multiple pathways capable of activating collybistin with differential cellular and subcellular specificity.

Mouse genetic studies have revealed that in vivo collybistin is required for the initial localization and maintenance of gephyrin 
and $\mathrm{GABA}_{\mathrm{A}} \mathrm{R}$ clusters in a subset of inhibitory synapses in selected brain regions, particularly in the hippocampus and basolateral amygdala (Papadopoulos et al., 2007, 2008). Surprisingly, deletion of collybistin did not affect the organization of GABAergic synapses in other regions, nor that of glycinergic synapses. These findings indicate that the mechanisms that control the assembly of the inhibitory PSD are region and synapse-specific. This selectivity may be explained by the fact that the expression of collybistin at inhibitory synapses is highly heterogeneous. In the retina, collybistin is preferentially colocalized with $\alpha 2-G_{A B A}$ Rs, and shows limited localization at synapses containing other $G_{A B A} R$ subtypes or GlyRs (Saiepour et al., 2010). Similarly, in brain circuits collybistin has been found in only a subset of gephyrin-positive synapse, although no specific association with particular $\mathrm{GABA}_{\mathrm{A}} \mathrm{R}$ subtypes was found (unpublished observations). These observations suggest that other GEFs or unknown clustering factors may also contribute to cluster gephyrin at postsynaptic sites. Interestingly, a recent study has revealed that SynArfGEF (also known as BRAG3 or IQSEC3), a member of the A-resistant Arf-GEF/IQSEC3 family, localizes at postsynaptic specializations of GABAergic and glycinergic synapses and can interact with dystrophin and SSCAM/Magi-2 (Fukaya et al., 2011). Thus, SynArfGEF is another GEF expressed at inhibitory synapses, although its precise function remains to be determined. It will be important to understand whether SynArfGEF, like collybistin, is associated with selected subtypes of inhibitory synapses, and whether these two GEFs have differential or partially overlapping distributions.

\section{SYNAPTIC SPECIFICITY DEPENDS ON MULTIPLE MECHANISMS}

A crucial and still open question in developmental neurobiology is to decipher the mechanisms that ensure the formation of functional connections between appropriate synaptic partners characterized by distinct molecular signatures. A large number of studies in both vertebrate and invertebrate nervous systems have shown that the specificity of synapses depends on multiple mechanisms, including homophilic and heterophilic interactions between adhesion molecules, secreted synaptic organizers, antisynaptogenic molecules, interactions with guidepost and/or glial cells, temporally restricted expression of transcription factors, and defined patterns of neuronal activity (for a recent review see Margeta and Shen, 2010). To illustrate the remarkable variety of the mechanisms that give rise to connectional specificity, we refer to recent work on cerebellar Purkinje cells. These neurons receive GABAergic inhibition mainly from basket cells, that target the cell body and the axon initial segment (AIS), and from stellate cells, that innervate exclusively the dendritic shafts (Palay and ChanPalay, 1974). Both types of synapse express the same $\mathrm{GABA}_{\mathrm{A}} \mathrm{R}$ subtype containing the $\alpha 1$ subunit (Fritschy et al., 2006). Studies in transgenic mouse models have shown that stellate and basket cells use different molecular cues to innervate distinct subcellular domains of Purkinje cells. The targeting of basket axons to the AIS depends on a subcellular gradient of neurofascin 186, a cell adhesion molecule of the L1 immunoglobulin family (Ango et al., 2004). This gradient requires ankyrinG, a membrane adaptor protein that is restricted to the AIS and recruits neurofascin. In ankyrinG-deficient Purkinje cells, the neurofascin gradient is abolished, and basket axons lose their directional growth along Purkinje cells, resulting in impaired synapse formation. On the other hand, the formation of stellate cell synapses depends on close homolog of L1 (CHL1), another member of the same family of adhesion molecules, localized along Bergmann glia fibers (Ango et al., 2008). Thus, different members of the L1 family of cell adhesion molecules contribute to axon patterning and subcellular synapse organization in different types of interneurons, although it seems that these molecules are more directly involved in axon guidance rather than in mediating synapse formation.

There is also evidence that $\mathrm{GABA}_{\mathrm{A}}$ Rs play a remarkably selective role in the refinement of perisomatic and axodendritic synapses in Purkinje cells. Deletion of $\mathrm{GABA}_{\mathrm{A}}$ Rs from Purkinje cells causes a selective decrease in the density of axodendritic synapses without altering the number of perisomatic synapses (Fritschy et al., 2006; Patrizi et al., 2008a). Notably, the reduced axodendritic innervation is accompanied by the appearance of numerous heterologous contacts between GABAergic axon terminals and Purkinje cell spines, which retain an asymmetric PSD typical of glutamatergic synapses (Fritschy et al., 2006).

These examples highlight two important aspects of synaptic specificity. First, the selectivity of connections does not depend on a hard-wired process based on exclusive cellular interactions, but rather results from a mechanism of selection among potential synaptic partners. In Purkinje cells, the silencing of GABAergic transmission is sufficient to boost ectopic synapses on spines, suggesting that in this specific case activity-dependent competition is a major determinant of synaptic specificity. Second, different synapses are subject to different regulation, implying that mutations that perturb synapse development in some populations of synapses may leave other synapses unaffected. This heterogeneity must be understood before common principles of synaptogenesis can be defined.

\section{COMPLEX ORGANIZATION OF ADHESION MOLECULES AT INHIBITORY SYNAPSES}

Once a synaptic adhesion has been established, it is essential that synaptic specializations recruit the correct complement of preand postsynaptic molecules, including the correct types of neurotransmitter receptors and their anchoring proteins. In the case of GABAergic synapses, it is still unknown how postsynaptic neurons cluster distinct types of $\mathrm{GABA}_{\mathrm{A}}$ Rs at synapses that can be located only a few micrometers apart. Selective interactions between preand postsynaptic adhesion molecules have been invoked to explain the selectivity in the segregation of different $\mathrm{GABA}_{\mathrm{A}}$ Rs (Thomson and Jovanovic, 2010). Indeed, there seems to be enough variability in the different families of synaptic adhesion molecules to support this function (Scheiffele, 2003; Yamagata et al., 2003; Washbourne et al., 2004; Craig et al., 2006; Piechotta et al., 2006; Dalva et al., 2007; Arikkath and Reichardt, 2008; Biederer and Stagi, 2008; Brose, 2009; Siddiqui and Craig, 2010; Tallafuss et al., 2010), although none of the known adhesion proteins appears to have a selective localization that would be compatible with a role in segregating distinct $\mathrm{GABA}_{\mathrm{A}}$ Rs to different synapses. Here we discuss the possibility that synapse diversity may result from the differential co-expression of multiple adhesion molecules with partially overlapping distributions. 
Neuroligin 2 is arguably the best characterized adhesion molecule of GABAergic synapses. This molecule belongs to a family of four (in rodents) isoforms, which appear to segregate into distinct types of excitatory and inhibitory synapses (Song et al., 1999; Craig and Kang, 2007). Neuroligin 2 is localized at postsynaptic sites of inhibitory synapses throughout the brain (Varoqueaux et al., 2004; Patrizi et al., 2008a), and promotes GABAergic synaptogenesis in vitro (Graf et al., 2004; Chih et al., 2006; Chubykin et al., 2007). Moreover, neuroligin 2 knockout mice exhibit selective deficits in GABAergic neurotransmission, indicating that this adhesion molecule is required for normal synapse development (Chubykin et al., 2007; Hoon et al., 2009; Jedlicka et al., 2011).

Recent studies have evidenced a complex organization of neuroligins at inhibitory synapses. While NL2 is present in practically all inhibitory synapses throughout the brain, other neuroligin isoforms have a more restricted distribution. Thus, NL4 is mainly associated with glycinergic synapses (Hoon et al., 2011), whereas NL3 is coexpressed with NL2 in subsets of GABAergic synapses (Budreck and Scheiffele, 2007; Patrizi et al., 2008b). These observations indicate that differential expression of neuroligins may confer specific functional properties to individual synapses, although the contribution of each individual neuroligin isoform remains unclear. Interestingly, recent research has indicated that NL2 has quite selective functions at GABAergic synapses, despite its broad distribution. In hippocampal pyramidal neurons, deletion of NL2 decreases the amplitude of IPSCs evoked from PV-positive interneurons, but has no effect on IPSCs evoked from somatostatin-positive cells (Gibson et al., 2009). A similar level of selectivity has been reported also for other cell adhesion molecules. For example, perturbation of the neural cell adhesion molecule (NCAM) produces selective effects on GABAergic synapses in frontal and cingulate cortex and in the amygdala, but not in hippocampus (Pillai-Nair et al., 2005). Together, these data reveal an unexpected variability in the synaptic properties conferred by individual cell adhesion molecules and provide support to the idea that synaptic specificity may be encoded by multiple interactions between selective combinations of synaptogenic proteins.

It is generally assumed that neuroligins promote synapse maturation by interacting with presynaptic neurexins (Ushkaryov et al., 1992; Graf et al., 2004; Chih et al., 2005; Kang et al., 2008). Neurexins occur in six different isoforms (three longer $\alpha$-neurexins and three shorter $\beta$-neurexins), that are further subject to alternative splicing, giving rise to several distinct variants that can bind with different affinities to multiple types of postsynaptic partners, including neuroligins, LRRTMs (leucine-rich repeat transmembrane neuronal proteins), neurexophilins, and the Cbln1-GluD2 (cerebellin 1-glutamate receptor $\delta 2$ ) complex (Ullrich et al., 1995; Missler and Südhof, 1998; Koehnke et al., 2010; Siddiqui and Craig, 2010; Uemura et al., 2010; Wright and Washbourne, 2011). In particular, the presence or the absence of an insert at splice site 4 (S4) appears to be an important determinant of binding partner selectivity (for review, see Craig and Kang, 2007; Siddiqui and Craig, 2010). Co-culture studies support a preferential role of $\alpha$-neurexins $(+S 4)$ in mediating GABAergic synaptogenesis (Boucard et al., 2005; Chih et al., 2006; Kang et al., 2008). Likewise, knockout of all $\alpha$-neurexins decreases considerably the density of GABAergic synapses in cortex (Missler et al., 2003). Interestingly, $\alpha$ neurexins can also interact with $\alpha$-dystroglycan (Sugita et al., 2001), which is present in a subset of GABAergic synapses as discussed above. Neurexins have also been reported to interact directly with $\mathrm{GABA}_{\mathrm{A}} \mathrm{Rs}$, although the importance of these interactions for synapse development is still unclear (Zhang et al., 2010). In summary, although there is clear evidence that both neuroligin 2 and $\alpha$-neurexins $(+S 4)$ promote GABAergic synaptogenesis in vitro, the extensive alternative splicing and numerous binding partners of neurexins suggest that these molecules may regulate synapse development by multiple, and not necessarily shared, mechanisms. As novel studies evidence that neuroligins can regulate glutamatergic synaptogenesis by neurexin independent mechanisms (Ko et al., 2009) and, vice versa, that neurexins induce the formation of glutamatergic synapses by interacting with postsynaptic molecules other than neuroligins (Uemura et al., 2010; Matsuda and Yuzaki, 2011), it appears reasonable to reevaluate the relevance of neurexin-neuroligin interactions in the context of inhibitory synapse development. It will also be of primary interest to understand what is the expression profile of the different neurexin isoforms in distinct types of excitatory and inhibitory synapses.

\section{SYNAPTIC CLEFT PROTEINS PROVIDE A FURTHER LEVEL OF COMPLEXITY}

An emerging concept is that proteins localized in the synaptic cleft may act bi-directionally to coordinate selective interactions between the pre- and postsynaptic compartments. By itself, this is not a new idea, as it is well established that at the neuromuscular junction secreted proteins, such as agrin and laminin, serve as synaptic organizers (Kummer et al., 2006; Witzemann, 2006; Rushton et al., 2009). Recently, a novel class of secreted molecules that link pre- and postsynaptic specializations has been characterized in the cerebellar cortex. Specifically, it has been shown that Cbln 1 acts as a crucial synaptic organizer that is required for the formation and maintenance of glutamatergic synapses made by parallel fibers with Purkinje cell spines (Yuzaki, 2010). Cbln1 is a glycoprotein of the $\mathrm{Clq}$ family that is secreted from cerebellar granule cells. Mice lacking Cbln1 are ataxic and show a surprising similarity to mice lacking the $\delta 2$ glutamate receptor (GluD2), which is expressed selectively in Purkinje cells. Both these mutants have a remarkable $(\sim 50 \%)$ reduction in the number of parallel fiber-Purkinje cell synapses, with the remaining synapses showing a mismatch between PSDs and presynaptic active zones, as well as impaired LTD (Kashiwabuchi et al., 1995, Kurihara et al., 1997, Hirai et al., 2005). The similarities in the structural and functional abnormalities observed in Cbln1-null and GluD2-null mice have suggested that these two molecules are engaged in a common signaling pathway. Indeed it has been demonstrated that Cbln 1 binds to the N-terminal domain of GluD2 (Matsuda et al., 2010), and that the Cbln1-GluD2 complex mediates synapse formation by interacting selectively with neurexins(+S4) (Uemura et al., 2010; Figure 2).

These new exciting findings show that secreted proteins can act as divalent ligands linking pre- and postsynaptic transmembrane components. Accordingly, the synaptic cleft can be regarded as the site in which secreted factors and cell adhesion molecules 
mediate trans-synaptic interactions that may contribute to encode synaptic specificity. For example, the ternary interaction between neurexin(+S4), Cbln1 and GluD2 may represent a "protein code" specific for parallel fiber-Purkinje cell synapses (Uemura et al., 2010). Notably, there is evidence that Cbln1 and the closely related Cbln2 can interact with neurexins and mediate synapse formation not only in cerebellum but also in forebrain regions (Matsuda and Yuzaki, 2011). Co-culture analyses have shown that Cbln1 and Cbln2 induce preferentially inhibitory presynaptic differentiation by interacting with neurexin variants containing $\$ 4$, although the postsynaptic partners remain unknown (Joo et al., 2011). It is therefore reasonable to assume that differential interactions of neurexin variants with neuroligins, Cbln and LRRTMs may be involved in specifying distinct types of excitatory and inhibitory synapses. By analogy, we suggest that trans-synaptic interactions mediated by $\alpha$-dystroglycan may constitute a molecular code for a specific subset of GABAergic synapses (Figure 2).

In short, cross-interactions between synaptic cleft proteins and cell adhesion molecules provide an additional level of complexity that could be exploited by neurons to functionally specify synapses. It is now a key task to increase our understanding of the synaptic extracellular matrix or synaptomatrix (Vautrin, 2010). Ultrastructural analyses have shown that this material is particularly dense, even denser than the neuronal cytosol, and is characterized by periodically organized complexes, suggesting a regular arrangement of cleft proteins (Zuber et al., 2005). Resolving the molecular interactions that occur in the synaptomatrix is likely to provide important insights into the mechanisms that underlie the formation and specificity of synapses.

\section{A MOLECULAR CATALOG OF INHIBITORY SYNAPSES}

The studies revised above have revealed an unexpected complexity in the molecules and mechanisms that control the assembly and specificity of inhibitory synapses during the formation of neural circuits. An important insight that has emerged from these investigations is that not all synaptic proteins are expressed equally at all inhibitory synapses, suggesting that synapse diversity is produced by unique combinations of synaptic molecules with
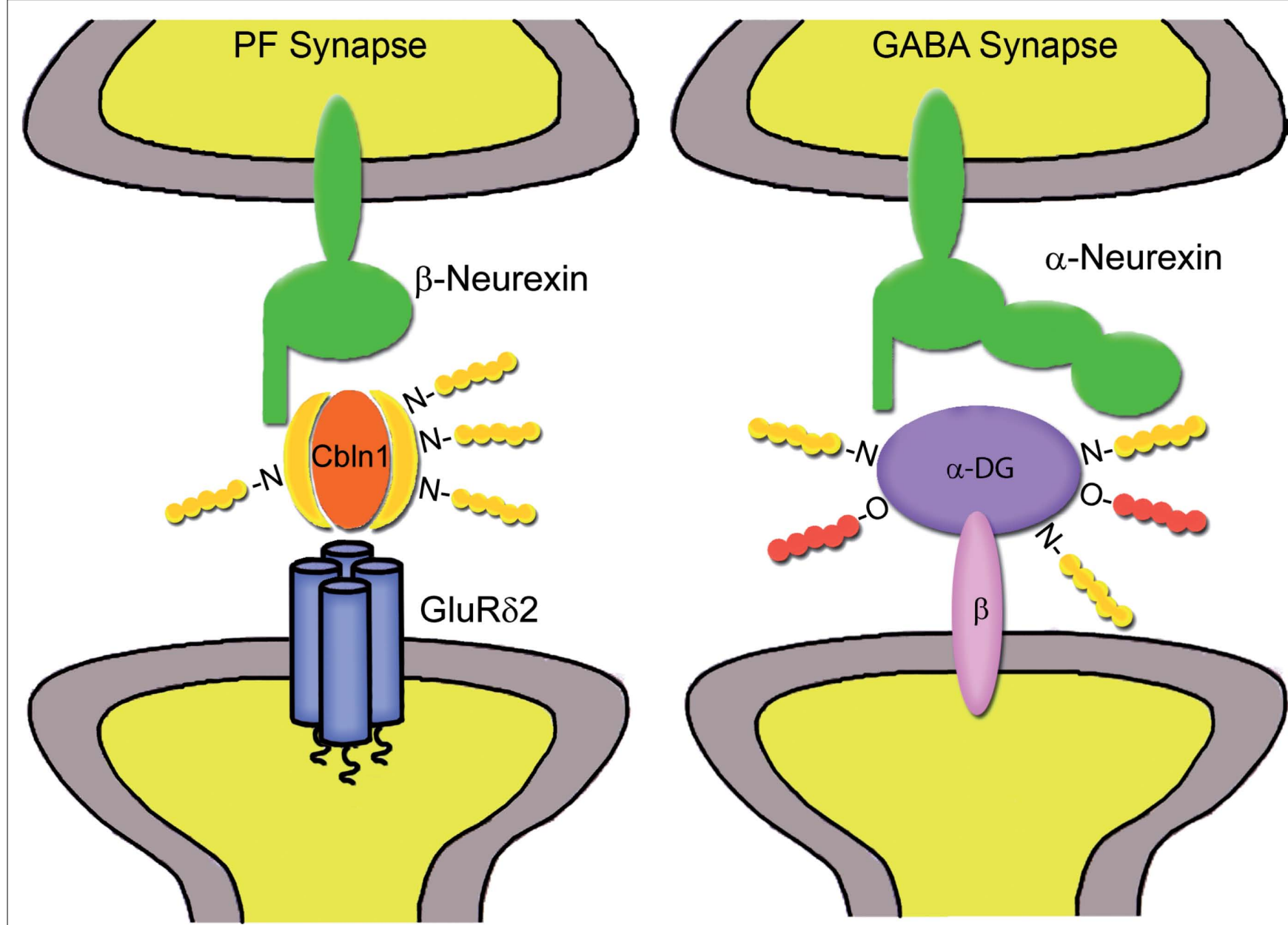

FIGURE 2 | Proposed trans-synaptic interactions mediated by synaptic cleft glycoproteins. At parallel fiber-Purkinje cell synapses (left), Cbln1 forms a ternary complex with neurexin variants containing the S4 insert and postsynaptic GluR $\delta 2$ receptors (modified from Uemura et al., 2010). At some GABAergic synapses (right), $\alpha$-dystroglycan ( $\alpha$-DG) may establish a link between $\alpha$-neurexins and the postsynaptic dystrophin-glycoprotein complex through the transmembrane $\beta$-dystroglycan isoform ( $\beta$-DG). Glycan side chains of Cbln1 and $\alpha$-DG may also mediate multiple interactions with extracellular matrix molecules. 
partially overlapping localizations and functions. The combinatorial expression of distinct sets of synaptic molecules may be regarded as a signature that identifies individual synapses and could be used to generate a molecular-based system of synapse categorization (Grant, 2007). A molecular catalog could be used to identify distinct types of synapses based on the differential expression of groups of interacting proteins, each contributing to specific aspects of synapse organization and physiology.

While the tremendous complexity of glutamatergic synapses poses a formidable challenge toward the accomplishment of a synapse catalog (Grant, 2007), a molecular characterization of inhibitory synapses appears to be within reach. A main obstacle is that our current list of synaptic proteins is not yet complete. Therefore a crucial step will be the identification of all proteins, including their splice variants and post-translational modifications. Expression screenings in co-culture systems represent a useful method for the identification of novel families of synaptogenic molecules (Paradis et al., 2007; Linhoff et al., 2009). On a larger scale, existing proteomic methods, such as mass spectrometry and protein array tools, can be applied to reveal protein-protein interactions (Husi et al., 2000; Schweitzer et al., 2003; Yuk et al., 2004; Collins and Choudhary, 2008). Bioinformatics tools could also be employed to generate hypothesis of interactions that could be verified experimentally and to construct interaction maps and models that could be used to predict the effects of mutations of single proteins (Armstrong et al., 2006).

Ideally, a categorization of synapses based on molecular markers should be combined with detailed knowledge of synaptic connectivity in situ, the ultimate goal being a convergence of synaptic proteomics with connectomics (Lichtman and Sanes, 2008). Considering the diversity and specificity of synapses, a full appreciation of their molecular complexity can be achieved only by microscopic analyses aimed at individual synapses. In this context, immunofluorescence methods are of particular interest because they combine high sensitivity with adequate resolution, and because they are suitable for large-scale analyses of protein distribution (Schneider Gasser et al., 2006; Sassoè-Pognetto, 2011). Moreover, labeling with multiple antibodies allows to determine whether two or more synaptic proteins colocalize at specific synapses. Recent developments, such as the advent of super-resolution light microscopy (Gustafsson, 2005; Hell, 2007; Nägerl et al., 2008), have considerably expanded the analytical power of immunofluorescence microscopy. In particular, array tomography is a new proteomic imaging method that exploits a combination of light and electron microscopic approaches (Micheva and Smith, 2007). This method consists in immunolabeling and imaging ordered arrays of ultrathin (50-200 nm), resin-embedded serial sections on glass microscopic slides, resulting in the acquisition of very large volume images at high resolution. Moreover, antibodies can be eluted and the sections restained a number of times thus allowing the detection of a large number of antigens in the same sample. Because of its proteomic capabilities and high resolution, array tomography represents a useful method for large-scale exploration of synaptic diversity. This method has been recently used to determine the composition of glutamatergic and GABAergic synapses in somatosensory cortex of Line-H-YFP Thy-1 transgenic mice (Micheva et al., 2010).
The potential of array tomography and other immunohistochemical methods is limited by the availability of antibodies that can be used to stain brain sections. In many cases the extensive sequence homology between related protein isoforms precludes the generation of specific antibodies. These technical difficulties may be overcome by labeling proteins directly by recombinant fusion protein technologies. For example, in a recent study $\mathrm{pH}$ sensitive pHluorin tagging was used to distinguish the membrane vs. intracellular pools of engineered neurexin $1 \alpha$ and neurexin $1 \beta$ in cortical organotypic cultures (Fu and Huang, 2010). In this study, the pHluorin-tagged neurexin isoforms were expressed in $\mathrm{PV}$-positive interneurons, allowing the visualization of their subaxonal localization and dynamics in a specific subset of GABAergic synapses. In another study, PSD-95-GFP was transfected by in utero electroporation in a specific population of cortical pyramidal neurons to monitor in vivo the dynamics of PSD-95 clusters using two-photon microscopy (Gray et al., 2006). While the expression of a tagged protein in isolated neurons may facilitate the visualization of its subcellular localization, the molecular cataloguing of synapses would require that the tagged proteins are expressed in vivo and replicate precisely the distribution patterns and expression levels of the endogenous proteins. Although the technology to perform this is potentially available, there have been no systematic analyses of synaptic protein distribution using this approach.

A full appreciation of the molecular diversity of synapses may help to uncover relationships between molecular composition and functional properties. In this context, the analysis of molecular organization should be complemented by gain or loss-of-function studies aimed at individual synaptic proteins in genetic model organisms. Likewise, a detailed knowledge of synaptic molecular composition may provide an interpretation key for the results obtained in knockout mutants, where the effects of the mutation are often confounded by the co-existence of multiple redundant molecular pathways (Piechotta et al., 2006). A synapse catalog could also be used to predict the consequences of mutations in the context of brain pathology and to identify populations of synapses that are likely to be affected in a particular disease (Grant, 2007). Finally, it will be of prime interest to consider how synapses vary over time, in particular by comparing synapse organization during the period of development and in mature circuits. As the last two decades have witnessed an impressive advancement in the identification of the molecular constituents of synapses (Südhof and Malenka, 2008), a big challenge ahead is to define the spatio-temporal expression profile of the endogenous synaptic proteins, to understand how this large array of molecules assemble into functional units, and to link the molecular data sets with a characterization of the anatomical and physiological diversity of synapses.

\section{ACKNOWLEDGMENTS}

Research in our laboratory is supported by Compagnia di San Paolo, Regione Piemonte (Ricerca Sanitaria Finalizzata 2008/bis and 2009), and Italian MIUR (Prin 2008KN7J7J). Giulia Pregno is the recipient of a fellowship from Fondazione CRT (Progetto Lagrange). 


\section{REFERENCES}

Alldred, M. J., Mulder-Rosi, J., Lingenfelter, S. E., Chen, G., and Luscher, B. (2005). Distinct $\gamma 2$ subunit domains mediate clustering and synaptic function of postsynaptic GABAA receptors and gephyrin. $J$. Neurosci. 25, 594-603.

Anderson, J. L., Head, S. I., and Morley, J. W. (2003). Altered inhibitory input to Purkinje cells of dystrophindeficient mice. Brain Res. 982, 280-283.

Ango, F., Di Cristo, G., Higashiyama, H., Bennett, V., Wu, P., and Huang, Z. J. (2004). Ankyrin-based subcellular gradient of neurofascin, an immunoglobulin family protein, directs GABAergic innervation at Purkinje axon initial segment. Cell 119, 257-272.

Ango, F., Wu, C., Van der Want, J. J., Wu, P., Schachner, M., and Huang, Z. J. (2008). Bergmann glia and the recognition molecule CHL1 organize GABAergic axons and direct innervation of Purkinje cell dendrites. PLoS Biol. 6, e103. doi: 10.1371/journal.pbio.0060103

Arikkath, J., and Reichardt, L. F. (2008). Cadherins and catenins at synapses: roles in synaptogenesis and synaptic plasticity. Trends Neurosci. 31, 487-494.

Armstrong, J. D., Pocklington, A. J., Cumiskey, M. A., and Grant, S. G. (2006). Reconstructing protein complexes: from proteomics to systems biology. Proteomics 6, 47244731.

Bausen, M., Fuhrmann, J. C., Betz, H., and O'sullivan, G. A. (2006). The state of the actin cytoskeleton determines its association with gephyrin: role of ena/VASP family members. Mol. Cell. Neurosci. 31, 376-386.

Bayés, A., Van de Lagemaat, L. N., Collins, M. O., Croning, M. D., Whittle, I. R., Choudhary, J. S., and Grant, S. G. (2011). Characterization of the proteome, diseases and evolution of the human postsynaptic density. Nat. Neurosci. 14, 19-21.

Benson, M. A., Newey, S. E., MartinRendon, E., Hawkes, R., and Blake, D. J. (2001). Dysbindin, a novel coiledcoil-containing protein that interacts with the dystrobrevins in muscle and brain. J. Biol. Chem. 276 24232-24241.

Biederer, T., and Stagi, M. (2008). Signaling by synaptogenic molecules. Curr. Opin. Neurobiol. 18, 261-269.

Blake, D. J., and Kröger, S. (2000). The neurobiology of duchenne muscular dystrophy: learning lessons from muscle? Trends Neurosci. 23, 92-99.
Boeckers, T. M. (2006). The postsynaptic density. Cell Tissue Res. 326, 409-422.

Boucard, A. A., Chubykin, A. A., Comoletti, D., Taylor, P., and Südhof, T C. (2005). A splice code for transsynaptic cell adhesion mediated by binding of neuroligin 1 to alpha- and beta-neurexins. Neuron 48, 229-236.

Bowe, M. A., Deyst, K. A., Leszyk, J. D., and Fallon, J. R. (1994). Identification and purification of an agrin receptor from Torpedo postsynaptic membranes: a heteromeric complex related to the dystroglycans. Neuron $12,1173-1180$.

Briatore, F., Patrizi, A., Viltono, L., Sassoè-Pognetto, M., and Wulff, P. (2010). Quantitative organization of GABAergic synapses in the molecular layer of the mouse cerebellar cortex. PLOS ONE 5, e12119. doi: 10.1371/journal.pone.0012119

Brose, N. (2009). Synaptogenic proteins and synaptic organizers: "many hands make light work". Neuron 61, 650-652.

Brünig, I., Suter, A., Knuesel, I., Lüscher B., and Fritschy, J. M. (2002). GABAergic terminals are required for postsynaptic clustering of dystrophin but not of GABAA receptors and gephyrin. J. Neurosci. 22, 4805-4813.

Budreck, E. C., and Scheiffele, P. (2007) Neuroligin-3 is a neuronal adhesion protein at GABAergic and glutamatergic synapses. Eur. J. Neurosci. 26, 1738-1748.

Charrier, C., Machado, P., TweedieCullen, R. Y., Rutishauser, D., Mansuy, I. M., and Triller, A. (2010). A crosstalk between $\beta 1$ and $\beta 3$ integrins controls glycine receptor and gephyrin trafficking at synapses. Nat. Neurosci. 13, 1388-1395.

Charych, E. I., Liu, F., Moss, S. J. and Brandon, N. J. (2009). GABAA receptors and their associated proteins: implications in the etiology and treatment of schizophrenia and related disorders. Neuropharmacology 57, 481-495.

Chih, B., Engelman, H., and Scheiffele, P. (2005). Control of excitatory and inhibitory synapse formation by neuroligins. Science 307, 1324-1328.

Chih, B., Gollan, L., and Scheiffele, P. (2006). Alternative splicing controls selective trans-synaptic interactions of the neuroligin-neurexin complex. Neuron 51, 171-178.

Chubykin, A. A., Atasoy, D., Etherton, M. R., Brose, N., Kavalali, E. T., Gibson, J. R., and Südhof, T. C. (2007). Activity-dependent validation of excitatory versus inhibitory synapses by neuroligin-1 versus neuroligin-2. Neuron 54, 919-931.

Collins, M. O., and Choudhary, J. S. (2008). Mapping multiprotein complexes by affinity purification and mass spectrometry. Curr. Opin. Biotechnol. 19, 324-330.

Collins, M. O., Yu, L., Coba, M. P., Husi, H., Campuzano, I., Blackstock, W. P., Choudhary, J. S., and Grant, S. G. (2005). Proteomic analysis of in vivo phosphorylated synaptic proteins. $J$. Biol. Chem. 280, 5972-5982.

Colonnier, M. (1968). Synaptic patterns on different cell types in the different laminae of the cat visual cortex An electron microscope study. Brain Res. 9, 268-287.

Craig, A. M., Graf, E. R., and Linhoff, M. W. (2006). How to build a central synapse: clues from cell culture. Trends Neurosci. 29, 8-20.

Craig, A. M., and Kang, Y. (2007). Neurexin-neuroligin signaling in synapse development. Curr. Opin. Neurobiol. 17, 43-52.

Dalva, M. B., McClelland, A. C., and Kayser, M. S. (2007). Cell adhesion molecules: signalling functions at the synapse. Nat. Rev. Neurosci. 8, 206-220.

Ervasti, J. M., and Campbell, K. P. (1991). Membrane organization of the dystrophin-glycoprotein complex. Cell 66, 1121-1131.

Essrich, C., Lorez, M., Benson, J. A., Fritschy, J. M., and Lüscher, B. (1998). Postsynaptic clustering of major GABAA receptor subtypes requires the $\gamma 2$ subunit and gephyrin. Nat. Neurosci. 1, 563-571.

Farrant, M., and Nusser, Z. (2005). Variations on an inhibitory theme: phasic and tonic activation of GABA(A) receptors. Nat. Rev. Neurosci. 6 215-229.

Feng, G., Tintrup, H., Kirsch, J., Nichol, M. C., Kuhse, J., Betz, H., and Sanes, J. R. (1998). Dual requirement for gephyrin in glycine receptor clustering and molybdoenzyme activity. Science 28, 1321-1324.

Fischer, F., Kneussel, M., Tintrup, H., Haverkamp, S., Rauen, T., Betz, H., and Wässle, H. (2000). Reduced synaptic clustering of GABA and glycine receptors in the retina of the gephyrin null mutant mouse. $J$. Comp. Neurol. 427, 634-648.

Freund, T. F., and Katona, I. (2007) Perisomatic inhibition. Neuron 56, 33-42.

Fritschy, J. M., Harvey, R. J., and Schwarz, G. (2008). Gephyrin: where do we stand, where do we go? Trends Neurosci. 31, 257-264.

Fritschy, J. M., Panzanelli, P., Kralic, J. E., Vogt, K., and Sassoè-Pognetto, M. (2006). Differential dependence of axo-dendritic and axo-somatic GABAergic synapses on GABAA receptors containing the $\alpha 1$ subunit in Purkinje cells. J. Neurosci. 26, 3245-3255.

Fu, Y., and Huang, Z. J. (2010). Differential dynamics and activitydependent regulation of $\alpha$ - and $\beta$ neurexins at developing GABAergic synapses. Proc. Natl. Acad. Sci. U.S.A 107, 22699-22704.

Fukaya, M., Kamata, A., Hara, Y., Tamaki, H., Katsumata, O., Ito, N. Takeda, S., Hata, Y., Suzuki, T., Watanabe, M., Harvey, R. J., and Sakagami, H. (2011). SynArfGEF is a guanine nucleotide exchange factor for Arf6 and localizes preferentially at post-synaptic specializations of inhibitory synapses. J. Neurochem. 116, 1122-1137.

Garner, C. C., Nash, J., and Huganir, R. L. (2000). PDZ domains in synapse assembly and signalling. Trends Cell Biol. 10, 274-280.

Gee, S. H., Montanaro, F., Lindenbaum, M. H., and Carbonetto, S. (1994). Dystroglycan- $\alpha$, a dystrophin-associated glycoprotein, is a functional agrin receptor. Cell 77, 675-686.

Gibson, J. R., Huber, K. M., and Südhof, T. C. (2009). Neuroligin-2 deletion selectively decreases inhibitory synaptic transmission originating from fast-spiking but not from somatostatin-positive interneurons. J. Neurosci. 29, 13883-13897.

Giesemann, T., Schwarz, G., Nawrotzki, R., Berhörster, K., Rothkegel, M. Schlüter, K., Schrader, N., Schindelin, H., Mendel, R. R., Kirsch, J., and Jockusch, B. M. (2003) Complex formation between the postsynaptic scaffolding protein gephyrin, profilin, and mena: a possible link to the microfilament system. J. Neurosci. 23, 8330-8339.

Grady, R. M., Wozniak, D. F., Ohlemiller, K. K., and Sanes, J. R. (2006). Cerebellar synaptic defects and abnormal motor behavior in mice lacking $\alpha$ and $\beta$-dystrobrevin. J. Neurosci. 26, 2841-2851.

Graf, E. R., Zhang, X., Jin, S. X, Linhoff, M. W., and Craig, A. M. (2004) Neurexins induce differentiation of GABA and glutamate postsynaptic specializations via neuroligins. Cell 119, 1013-1026.

Grant, S. G. (2007). Toward a molecular catalogue of synapses. Brain Res. Rev. 55, 445-449.

Gray, E. G. (1959). Axo-somatic and axo-dendritic synapses of the cerebral cortex: an electron microscope study. J. Anat. 93, 420-433. 
Gray, N. W., Weimer, R. M., Bureau, I., and Svoboda, K. (2006). Rapid redistribution of synaptic PSD-95 in the neocortex in vivo. PLoS Biol. 4, e370. doi: 10.1371/journal.pbio.0040370

Gustafsson, M. G. (2005). Nonlinear structured-illumination microscopy: wide-field fluorescence imaging with theoretically unlimited resolution. Proc. Natl. Acad. Sci. U.S.A. 102, 13081-13086.

Harvey, K., Duguid, I. C., Alldred, M. J., Beatty, S. E., Ward, H., Keep, N. H., Lingenfelter, S. E., Pearce, B. R., Lundgren, J., Owen, M. J., Smart, T. G., Lüscher, B., Rees, M. I., and Harvey, R. J. (2004). The GDPGTP exchange factor collybistin: an essential determinant of neuronal gephyrin clustering. J. Neurosci. 24, 5816-5826.

Hell, S. W. (2007). Far-field optical nanoscopy. Science 316, 1153-1158.

Hirai, H., Pang, Z., Bao, D., Miyazaki, T., Li, L., Miura, E., Parris, J., Rong, Y., Watanabe, M., Yuzaki, M., and Morgan, J. I. (2005). Cbln1 is essential for synaptic integrity and plasticity in the cerebellum. Nat. Neurosci. 8 , 1534-1541.

Hirao, K., Hata, Y., Ide, N., Takeuchi, M., Irie, M., Yao, I., Deguchi, M., Toyoda, A., Sudhof, T. C., and Takai, Y. (1998). A novel multiple PDZ domain-containing molecule interacting with $\mathrm{N}$-methyl-D-aspartate receptors and neuronal cell adhesion proteins. J. Biol. Chem. 273, 21105-21110.

Hoon, M., Bauer, G., Fritschy, J. M., Moser, T., Falkenburger, B. H., and Varoqueaux, F. (2009). Neuroligin 2 controls the maturation of GABAergic synapses and information processing in the retina. J. Neurosci. 29, 8039-8050.

Hoon, M., Soykan, T., Falkenburger, B., Hammer, M., Patrizi, A., Schmidt, K. F., Sassoè-Pognetto, M., Löwel, S., Moser, T., Taschenberger, H., Brose, N., and Varoqueaux, F. (2011). Neuroligin-4 is localized to glycinergic postsynapses and regulates inhibition in the retina. Proc. Natl. Acad. Sci. U.S.A. 108, 3053-3058.

Huang, Z. J., Di Cristo, G., and Ango, F. (2007). Development of GABA innervation in the cerebral and cerebellar cortices. Nat. Rev. Neurosci. 8 , 673-686.

Husi, H., Ward, M. A., Choudhary, J. S., Blackstock, W. P., and Grant, S. G. (2000). Proteomic analysis of NMDA receptor-adhesion protein signaling complexes. Nat. Neurosci. 3, 661-669.

Ibraghimov-Beskrovnaya, O., Ervasti, J. M., Leveille, C. J., Slaughter, C.
A., Sernett, S. W., and Campbell, K. P. (1992). Primary structure of dystrophin-associated glycoproteins linking dystrophin to the extracellular matrix. Nature 355, 696-702.

Iida, J., Hirabayashi, S., Sato, Y., and Hata, Y. (2004). Synaptic scaffolding molecule is involved in the synaptic clustering of neuroligin. Mol. Cell. Neurosci. 27, 497-508.

Jacob, T. C., Bogdanov, Y. D., Magnus, C., Saliba, R. S., Kittler, J. T., Haydon, P. G., and Moss, S. J. (2005). Gephyrin regulates the cell surface dynamics of synaptic GABAA receptors. J. Neurosci. 25, 10469-10478.

Jedlicka, P., Hoon, M., Papadopoulos, T., Vlachos, A., Winkels, R., Poulopoulos, A., Betz, H., Deller, T., Brose, N., Varoqueaux, F., and Schwarzacher, S. W. (2011). Increased dentate gyrus excitability in neuroligin-2-deficient mice in vivo. Cereb. Cortex 21, 357-367.

Joo, J. Y., Lee, S. J., Uemura, T., Yoshida, T., Yasumura, M., Watanabe, M., and Mishina, M. (2011). Differential interactions of cerebellin precursor protein (Cbln) subtypes and neurexin variants for synapse formation of cortical neurons. Biochem. Biophys. Res. Commun. 406, 627-632.

Kang, Y., Zhang, X., Dobie, F., Wu, H., and Craig, A. M. (2008). Induction of GABAergic postsynaptic differentiation by $\alpha$-neurexins. J. Biol. Chem . 283, 2323-2334.

Kashiwabuchi, N., Ikeda, K., Araki, K., Hirano, T., Shibuki, K., Takayama, C., Inoue, Y., Kutsuwada, T., Yagi, T. Kang, Y., Aizawae, S., and Mishina, M. (1995). Impairment of motor coordination, Purkinje cell synapse formation, and cerebellar long-term depression in GluR $\delta 2$ mutant mice. Cell 81, 245-252.

Kennedy, M. B. (1997). The postsynaptic density at glutamatergic synapses. Trends Neurosci. 20, 264-268.

Kim, E., and Sheng, M. (2004). PDZ domain proteins of synapses. Nat. Rev. Neurosci. 5, 771-781.

Kim, M. J., Futai, K., Jo, J., Hayashi, Y., Cho, K., and Sheng, M. (2007). Synaptic accumulation of PSD-95 and synaptic function regulated by phosphorylation of serine-295 of PSD-95. Neuron 56, 488-502.

Kins, S., Betz, H., and Kirsch, J. (2000). Collybistin, a newly identified brainspecific GEF, induces submembrane clustering of gephyrin. Nat. Neurosci. 3, 22-29.

Kirsch, J., and Betz, H. (1995) The postsynaptic localization of the glycine receptor-associated protein gephyrin is regulated by the cytoskeleton. J. Neurosci. 15, 4148-4156.

Kirsch, J., Langosch, D., Prior, P., Littauer, U. Z., Schmitt, B., and Betz, H. (1991). The 93-kDa glycine receptor-associated protein binds to tubulin. J. Biol. Chem. 266, 22242-22245

Kirsch, J., Wolters, I., Triller, A., and Betz, H. (1993). Gephyrin antisense oligonucleotides prevent glycine receptor clustering in spinal neurons. Nature 366, 745-748.

Klausberger, T., Roberts, J. D., and Somogyi, P. (2002). Cell type- and inputspecific differences in the number and subtypes of synaptic GABAA receptors in the hippocampus. $J$. Neurosci. 22, 2513-2521.

Klausberger, T., and Somogyi, P. (2008). Neuronal diversity and temporal dynamics: the unity of hippocampal circuit operations. Science 321 , 53-57.

Kneussel, M., Brandstätter, J. H., Laube, B., Stahl, S., Müller, U., and Betz, H. (1999). Loss of postsynaptic GABAA receptor clustering in gephyrin-deficient mice. J. Neurosci. 19, 9289-9297.

Kneussel, M., Brandstätter, J. H., Gasnier, B., Feng, G., Sanes, J. R., and Betz, H. (2001). Gephyrinindependent clustering of postsynaptic GABAA receptor subtypes. Mol. Cell. Neurosci. 17, 973-982.

Kneussel, M., and Betz, H. (2000). Receptors, gephyrin and gephyrinassociated proteins: novel insight into the assembly of inhibitory postsynaptic membrane specializations. J. Physiol. 5251, 1-9.

Knuesel, I., Mastrocola, M., Zuellig, R. A., Bornhauser, B., Schaub, M. C., and Fritschy, J. M. (1999). Short communication: altered synaptic clustering of GABAA receptors in mice lacking dystrophin ( $\mathrm{mdx}$ mice). Eur. J. Neurosci. 11, 4457-4462.

Ko, J., Zhang, C., Arac, D., Boucard, A. A., Brunger, A. T., and Südhof, T. C. (2009). Neuroligin-1 performs neurexin-dependent and neurexinindependent functions in synapse validation. EMBO J. 28, 3244-3255.

Koehnke, J., Katsamba, P. S., Ahlsen. G., Bahna, F., Vendome, J., Honig, B., Shapiro, L., and Jin, X. (2010). Splice form dependence of betaneurexin/neuroligin binding interactions. Neuron 67, 61-74.

Kralic, J. E., Sidler, C., Parpan, F., Homanics, G. E., Morrow, A. L., and Fritschy, J. M. (2006). Compensatory alteration of inhibitory synaptic circuits in cerebellum and thalamus of gamma-aminobutyric acid type
A receptor alphal subunit knockout mice. J. Comp. Neurol. 495, 408-421.

Kueh, S. L., Head, S. I., and Morley, J. W. (2008). GABAA receptor expression and inhibitory post-synaptic currents in cerebellar Purkinje cells in dystrophin-deficient $\mathrm{mdx}$ mice. Clin. Exp. Pharmacol. Physiol. 35, 207-210.

Kummer, T. T., Misgeld. T., and Sanes, J. R. (2006). Assembly of the postsynaptic membrane at the neuromuscular junction: paradigm lost. Curr. Opin. Neurobiol. 16, 74-82.

Kurihara, H., Hashimoto, K., Kano, M., Takayama, C., Sakimura, K., Mishina, M., Inoue, Y., and Watanabe, M. (1997). Impaired parallel fiber Purkinje cell synapse stabilization during cerebellar development of mutant mice lacking the glutamate receptor $\delta 2$ subunit. J. Neurosci. 17, 9613-9623.

Lévi, S., Grady, R. M., Henry, M. D., Campbell, K. P., Sanes, J. R., and Craig, A. M. (2002). Dystroglycan is selectively associated with inhibitory GABAergic synapses but is dispensable for their differentiation. J. Neurosci. 22, 4274-4285.

Lévi, S., Logan, S. M., Tovar, K. R., and Craig, A. M. (2004). Gephyrin is critical for glycine receptor clustering but not for the formation of functional GABAergic synapses in hippocampal neurons. J. Neurosci. 24, 207-217.

Lewis, D. A., Hashimoto, T., and Volk, D. W. (2005). Cortical inhibitory neurons and schizophrenia. Nat. Rev. Neurosci. 6, 312-324.

Li, R. W., Yu, W., Christie, S. B., Miralles, C. P., Bai, J., Loturco, J. J., and De Blas, A. L. (2005). Disruption of postsynaptic GABA receptor clusters leads to decreased GABAergic innervation of pyramidal neurons. $J$. Neurochem. 95, 756-770.

Lichtman, J. W., and Sanes, J. R. (2008). Ome sweet ome: what can the genome tell us about the connectome? Curr. Opin. Neurobiol. 18, 346-353.

Linhoff, M. W., Laurén, J., Cassidy, R. M., Dobie, F. A., Takahashi, H., Nygaard, H. B., Airaksinen, M. S. Strittmatter, S. M., and Craig, A. M. (2009). An unbiased expression screen for synaptogenic proteins identifies the LRRTM protein family as synaptic organizers. $\mathrm{Neu}$ ron $61,734-749$.

Lüscher, B., and Keller, C. A. (2004). Regulation of GABAA receptor trafficking, channel activity, and functional plasticity of inhibitory synapses. Pharmacol. Ther. 102, 195-221. 
Mammoto, A., Sasaki, T., Asakura, T., Hotta, I., Imamura, H., Takahashi, K., Matsuura, Y., Shirao, T., and Takai, Y. (1998). Interactions of drebrin and gephyrin with profilin. Biochem. Biophys. Res. Commun. 243, 86-89.

Margeta, M. A., and Shen, K. (2010). Molecular mechanisms of synaptic specificity. Mol. Cell. Neurosci. 43, 261-267.

Markram, H., Toledo-Rodriguez, M., Wang, Y., Gupta, A., Silberberg, G., and $\mathrm{Wu}, \mathrm{C}$. (2004). Interneurons of the neocortical inhibitory system. Nat. Rev. Neurosci. 5, 793-807.

Matsuda, K., Miura, E., Miyazaki, T., Kakegawa, W., Emi, K., Narumi, S., Fukazawa, Y., Ito-Ishida, A., Kondo, T., Shigemoto, R., Watanabe, M., and Yuzaki, M. (2010). Cbln1 is a ligand for an orphan glutamate receptor $\delta 2$, a bidirectional synapse organizer. Science 328, 363-368.

Matsuda, K., and Yuzaki, M. (2011). Cbln family proteins promote synapse formation by regulating distinct neurexin signaling pathways in various brain regions. Eur. J. Neurosci. 33, 1447-1461.

McKernan, R. M., Rosahl, T. W., Reynolds, D. S., Sur, C., Wafford, K. A., Atack, J. R., Farrar, S., Myers, J., Cook, G., Ferris, P., Garrett, L., Bristow, L., Marshall, G., Macaulay, A., Brown, N., Howell, O., Moore, K. W., Carling, R. W., Street, L. J., Castro, J. L., Ragan, C. I., Dawson, G. R., and Whiting, P. J. (2000). Sedative but not anxiolytic properties of benzodiazepines are mediated by the GABAA receptor $\alpha 1$ subtype. Nat. Neurosci. 3, 587-592.

Meyer, G., Kirsch, J., Betz, H., and Langosch, D. (1995). Identification of a gephyrin binding motif on the glycine receptor beta subunit. $\mathrm{Neu}$ ron $15,563-572$.

Micheva, K. D., Busse, B., Weiler, N. C., O'Rourke, N., and Smith, S. J. (2010). Single-synapse analysis of a diverse synapse population: proteomic imaging methods and markers. Neuron 68, 639-653.

Micheva, K. D., and Smith, S. J. (2007). Array tomography: a new tool for imaging the molecular architecture and ultrastructure of neural circuits. Neuron 55, 25-36.

Missler, M., and Südhof, T. C. (1998). Neurexins: three genes and 1001 products. Trends Genet. 14, 20-26.

Missler, M., Zhang, W., Rohlmann, A., Kattenstroth, G., Hammer, R. E., Gottmann, K., and Südhof, T. C. (2003). Alpha-neurexins couple $\mathrm{Ca}^{2+}$ channels to synaptic vesicle exocytosis. Nature 26, 939-948.
Möhler, H. (2006). GABAA receptor diversity and pharmacology. Cell Tissue Res. 326, 505-516.

Möhler, H. (2007). Molecular regulation of cognitive functions and developmental plasticity: impact of GABAA receptors. J. Neurochem. 102, 1-12.

Monyer, H., and Markram, H. (2004). Interneuron diversity series: molecular and genetic tools to study GABAergic interneuron diversity and function. Trends Neurosci. 27, 90-97.

Nägerl, U. V., Willig, K. I., Hein, B., Hell, S. W., and Bonhoeffer, T. (2008). Live-cell imaging of dendritic spines by STED microscopy. Proc. Natl. Acad. Sci. U.S.A. 105, 18982-18987.

O'Brien, R. J., Lau, L. F., and Huganir, R. L. (1998). Molecular mechanisms of glutamate receptor clustering at excitatory synapses. Curr. Opin. Neurobiol. 8, 364-369.

Olsen, R. W., and Sieghart, W. (2009). GABAA receptors: subtypes provide diversity of function and pharmacology. Neuropharmacology 56, 141-148.

Paarmann, I., Saiyed, T., Schmitt, B., and Betz, H. (2006). Gephyrin: does splicing affect its function? Biochem. Soc. Trans. 34, 45-47.

Palay, S., and Chan-Palay, V. (1974). Cerebellar Cortex: Cytology and Organization. Berlin: Springer.

Papadopoulos, T., Eulenburg, V., ReddyAlla, S., Mansuy, I. M., Li, Y., and Betz, H. (2008). Collybistin is required for both the formation and maintenance of GABAergic postsynapses in the hippocampus. Mol. Cell. Neurosci. 39, 161-169.

Papadopoulos, T., Korte, M., Eulenburg, V., Kubota, H., Retiounskaia, M., Harvey, R. J., Harvey, K., O’Sullivan, G. A., Laube, B., Hülsmann, S., Geiger, J. R., and Betz, H. (2007). Impaired GABAergic transmission and altered hippocampal synaptic plasticity in collybistin-deficient mice. EMBO J. 26, 3888-3899.

Paradis, S., Harrar, D. B., Lin, Y., Koon, A. C., Hauser, J. L., Griffith, E. C., Zhu, L., Brass, L. F., Chen, C., and Greenberg, M. E. (2007). An RNAi-based approach identifies molecules required for glutamatergic and GABAergic synapse development. Neuron 53, 217-232.

Patrizi, A., Scelfo, B., Viltono, L., Briatore, F., Fukaya, M., Watanabe, M., Strata, P., Varoqueaux, F., Brose, N., Fritschy, J. M., and SassoèPognetto, M. (2008a). Synapse formation and clustering of neuroligin2 in the absence of GABAA receptors. Proc. Natl. Acad. Sci. U.S.A. 105 , 13151-13156.
Patrizi, A., Poulopoulos, A., Brose N., Varoqueaux, F., and SassoèPognetto, M. (2008b). In vivo Localization of Neuroligin-3 at Inhibitory Postsynaptic Specializations. Program No. 325.19/B46. 2008 Abstract Viewer/Itinerary Planner. Washington, DC: Society for Neuroscience.

Perronnet, C., and Vaillend, C. (2010). Dystrophins, utrophins, and associated scaffolding complexes: role in mammalian brain and implications for therapeutic strategies. J. Biomed. Biotechnol. 2010, 849426.

Peters, A., and Palay, S. L. (1996). The morphology of synapses. J. Neurocytol. 25, 687-700.

Pfeiffer, F., Graham, D., and Betz, H (1982). Purification by affinity chromatography of the glycine receptor of rat spinal cord. J. Biol. Chem. 257, 9389-9393.

Piechotta, K., Dudanova, I., and Missler, M. (2006). The resilient synapse: insights from genetic interference of synaptic cell adhesion molecules. Cell Tissue Res. 326, 617-642.

Pillai-Nair, N., Panicker, A. K. Rodriguiz, R. M., Gilmore, K. L., Demyanenko, G. P., Huang, J. Z., Wetsel, W. C., and Maness, P. F. (2005). Neural cell adhesion molecule-secreting transgenic mice display abnormalities in GABAergic interneurons and alterations in behavior. J. Neurosci. 25, 4659-4671.

Poulopoulos, A., Aramuni, G. Meyer, G., Soykan, T., Hoon, M., Papadopoulos, T., Zhang, M., Paarmann, I., Fuchs, C., Harvey, K., Jedlicka, P., Schwarzacher, S W., Betz, H., Harvey, R. J., Brose, N., Zhang, W., and Varoqueaux, F. (2009). Neuroligin 2 drives postsynaptic assembly at perisomatic inhibitory synapses through gephyrin and collybistin. Neuron 63 628-642.

Reddy-Alla, S., Schmitt, B., Birkenfeld, J., Eulenburg, V., Dutertre, S., Böhringer, C., Götz, M., Betz, H., and Papadopoulos, T. (2010). PHdomain-driven targeting of collybistin but not $\mathrm{Cdc} 42$ activation is required for synaptic gephyrin clustering. Eur. J. Neurosci. 31, 1173-1184.

Rushton, E., Rohrbough, J., and Broadie K. (2009). Presynaptic secretion of mind-the-gap organizes the synaptic extracellular matrix-integrin interface and postsynaptic environments. Dev. Dyn. 238, 554-571.

Saiepour, L., Fuchs, C., Patrizi, A. Sassoè-Pognetto, M., Harvey, R. J., and Harvey, K. (2010). Complex role of collybistin and gephyrin in GABAA receptor clustering. J. Biol. Chem. 285, 29623-29631.
Sassoè-Pognetto, M. (2011). Molecular and functional heterogeneity of neural circuits: an example from the olfactory bulb. Brain Res. Rev. 66, 35-42.

Sassoè-Pognetto, M., and Fritschy, J. M. (2000). Mini-review: gephyrin, a major postsynaptic protein of GABAergic synapses. Eur. J. Neurosci. 12, 2205-2210.

Sassoè-Pognetto, M., Kirsch, J., Grünert, U., Greferath, U., Fritschy, J. M., Möhler, H., Betz, H., and Wässle, H. (1995). Colocalization of gephyrin and GABAA-receptor subunits in the rat retina. J. Comp. Neurol. 357, $1-14$.

Sassoè-Pognetto, M., Panzanelli, P., Sieghart, W., and Fritschy, J. M (2000). Colocalization of multiple GABAA receptor subtypes with gephyrin at postsynaptic sites. J. Comp. Neurol. 420, 481-498.

Sato, S., Omori, Y., Katoh, K., Kondo, M., Kanagawa, M., Miyata, K., Funabiki, K., Koyasu, T., Kajimura, N., Miyoshi, T., Sawai, H., Kobayashi, K., Tani, A., Toda, T., Usukura, J., Tano, Y., Fujikado, T., and Furukawa, T. (2008). Pikachurin, a dystroglycan ligand, is essential for photoreceptor ribbon synapse formation. Nat Neurosci. 11, 923-931.

Scannevin, R. H., and Huganir, R. L. (2000). Postsynaptic organization and regulation of excitatory synapses. Nat. Rev. Neurosci. 1, 133-141.

Scheiffele, P. (2003). Cell-cell signaling during synapse formation in the CNS. Annu. Rev. Neurosci. 26, 485-508.

Schneider Gasser, E. M., Straub, C. J., Panzanelli, P., Weinmann, O., Sassoè-Pognetto, M., and Fritschy, J. M. (2006). Immunofluorescence in brain sections: simultaneous detection of pre- and postsynaptic proteins in identified neurons. Nat. Protoc. 1, 1887-1897.

Schweitzer, B., Predki, P., and Snyder, M. (2003). Microarrays to characterize protein interactions on a whole-proteome scale. Proteomics 3, 2190-2199.

Schweizer, C., Balsiger, S., Bluethmann, H., Mansuy, I. M., Fritschy, J. M. Mohler, H., and Lüscher, B. (2003). The $\gamma 2$ subunit of GABAA receptors is required for maintenance of receptors at mature synapses. Mol. Cell. Neurosci. 24, 442-450.

Sekiguchi, M., Zushida, K., Yoshida, M., Maekawa, M., Kamichi, S., Yoshida, M., Sahara, Y., Yuasa, S., Takeda, S., and Wada, K. (2009). A deficit of brain dystrophin impairs specific amygdala GABAergic transmission and enhances defensive behaviour in mice. Brain 132, 124-135 
Siddiqui, T. J., and Craig, A. M. (2010). Synaptic organizing complexes. Curr. Opin. Neurobiol. 21, 132-143.

Sohal, V. S., Zhang, F., Yizhar, O., and Deisseroth, K. (2009). Parvalbumin neurons and gamma rhythms enhance cortical circuit performance. Nature 459, 698-702.

Song. J. Y., Ichtchenko, K., Südhof, T. C., and Brose, N. (1999). Neuroligin 1 is a postsynaptic cell-adhesion molecule of excitatory synapses. Proc. Natl. Acad. Sci. U.S.A. 96, 1100-1105.

Steiner, P., Higley, M. J., Xu, W., Czervionke, B. L., Malenka, R. C., and Sabatini, B. L. (2008). Destabilization of the postsynaptic density by PSD-95 serine 73 phosphorylation inhibits spine growth and synaptic plasticity. Neuron 60, 788-802.

Studer, R., von Boehmer, L., Haenggi, T., Schweizer, C., Benke, D., Rudolph, U., and Fritschy, J. M. (2006). Alteration of GABAergic synapses and gephyrin clusters in the thalamic reticular nucleus of GABAA receptor $\alpha 3$ subunit-null mice. Eur. J. Neurosci. 24, 1307-1315.

Südhof, T. C. (2008). Neuroligins and neurexins link synaptic function to cognitive disease. Nature 455, 903-911.

Südhof, T. C., and Malenka, R. C. (2008). Understanding synapses: past, present, and future. Neuron 60 , 469-476.

Sugita, S., Saito, F., Tang, J., Satz, J., Campbell, K., and Südhof, T. C. (2001). A stoichiometric complex of neurexins and dystroglycan in brain. J. Cell Biol. 154, 435-445.

Sumita, K., Sato, Y., Iida, J., Kawata, A., Hamano, M., Hirabayashi, S., Ohno, K., Peles, E., and Hata, Y. (2007). Synaptic scaffolding molecule (S-SCAM) membraneassociated guanylate kinase with inverted organization (MAGI)-2 is associated with cell adhesion molecules at inhibitory synapses in rat hippocampal neurons. J. Neurochem. 100, 154-166.

Talbot, K., Ong, W.-Y., Blake, D. J., Tang, J., Louneva, N., Carlson, G. C., and Arnold, S. E. (2009). "Dysbindin1 and its protein family," in Handbook of Neurochemistry and Molecular Neurobiology: Schizophrenia, 3rd Edn, Vol. 27, eds D. C. Javitt and
J. Kantrowitz (New York: Springer Science), 107-241.

Tallafuss, A., Constable, J. R., and Washbourne, P. (2010). Organization of central synapses by adhesion molecules. Eur. J. Neurosci. 32, 198-206.

Talts, J. F., Andac, Z., Göhring, W., Brancaccio, A., and Timpl, R. (1999). Binding of the $G$ domains of laminin $\alpha 1$ and $\alpha 2$ chains and perlecan to heparin, sulfatides, $\alpha$ dystroglycan and several extracellular matrix proteins. EMBO J. 18, 863-870.

Thomas, P., Mortensen, M., Hosie, A. M., and Smart, T. G. (2005). Dynamic mobility of functional GABAA receptors at inhibitory synapses. Nat. Neurosci. 8, 889-897.

Thomson, A. M., and Jovanovic, J. N. (2010). Mechanisms underlying synapse-specific clustering of GABAA receptors. Eur. J. Neurosci. 31, 2193-2203.

Tretter, V., and Moss, S. J. (2008) GABAA receptor dynamics and constructing GABAergic synapses. Front. Mol. Neurosci. 1:7. doi: 10.3389/neuro.02.007.2008

Tyagarajan, S. K., Ghosh, H., Yévenes, G. E., Nikonenko, I., Ebeling, C., Schwerdel, C., Sidler, C., Zeilhofer, H. U., Gerrits, B., Muller, D., and Fritschy, J. M. (2011). Regulation of GABAergic synapse formation and plasticity by GSK3 $\beta$-dependent phosphorylation of gephyrin. Proc. Natl. Acad. Sci. U.S.A. 108, 379-384.

Uemura, T., Lee, S. J., Yasumura, M., Takeuchim, T., Yoshida, T., Ra, M., Taguchi, R., Sakimura, K., and Mishina, M. (2010). Trans-synaptic interaction of GluR $\delta 2$ and Neurexin through Cbln1 mediates synapse formation in the cerebellum. Cell 141, 1068-1079.

Ullrich, B., Ushkaryov, Y. A., and Südhof, T. C. (1995). Cartography of neurexins: more than 1000 isoforms generated by alternative splicing and expressed in distinct subsets of neurons. Neuron 14, 497-507.

Ushkaryov, Y. A., Petrenko, A. G., Geppert, M., and Südhof, T. C. (1992). Neurexins: synaptic cell surface proteins related to the alpha-latrotoxin receptor and laminin. Science 257, 50-56.

Vaillend, C., Perronnet, C., Ros, C., Gruszczynski, C., Goyenvalle, A., Laroche, S., Danos, O., Garcia, L. and Peltekian, E. (2010). Rescue of a dystrophin-like protein by exon skipping in vivo restores GABAA receptor clustering in the hippocampus of the mdx mouse. Mol. Ther. 18, 1683-1688.

Varoqueaux, F., Jamain, S., and Brose, N. (2004). Neuroligin 2 is exclusively localized to inhibitory synapses. Eur. J. Cell Biol. 83, 449-456.

Vautrin, J. (2010). The synaptomatrix: a solid though dynamic contact disconnecting transmissions from exocytotic events. Neurochem. Int. 57, 85-96.

Viltono, L., Patrizi, A., Fritschy, J. M., and Sassoè-Pognetto, M. (2008) Synaptogenesis in the cerebellar cortex: differential regulation of gephyrin and GABAA receptors at somatic and dendritic synapses of Purkinje cells. J. Comp. Neurol. 508 579-591.

Waite, A., Tinsley, C. L., Locke, M., and Blake, D. J. (2009). The neurobiology of the dystrophin-associated glycoprotein complex. Ann. Med. 41, 344-359.

Washbourne, P., Dityatev, A., Scheiffele, P., Biederer, T., Weiner, J.A, Christopherson, K. S., and El-Husseini, A. (2004). Cell adhesion molecules in synapse formation. J. Neurosci. 24 , 9244-9249.

Whiting, P. J. (2006). GABAA receptors: a viable target for novel anxiolytics? Curr. Opin. Pharmacol. 6, 24-29.

Witzemann, V. (2006). Development of the neuromuscular junction. Cell Tissue Res. 326, 263-271.

Wright, G. J., and Washbourne, P. (2011). Neurexins, Neuroligins and LRRTMs: synaptic adhesion getting fishy. J. Neurochem. 117, 765-778.

Yamagata, M., Sanes, J. R., and Weiner, J. A. (2003). Synaptic adhesion molecules. Curr. Opin. Cell Biol. 15, 621-632.

Yamakawa, H., Oyama, S., Mitsuhashi, H., Sasagawa, N., Uchino, S. Kohsaka, S., and Ishiura, S. (2007). Neuroligins 3 and $4 \mathrm{X}$ interact with syntrophin- $\gamma 2$, and the interactions are affected by autism-related mutations. Biochem. Biophys. Res. Commun. 355, 41-46.

Yu, W., Jiang, M., Miralles, C. P., Li, R. W., Chen, G., and De Blas, A. L. (2007). Gephyrin clustering is required for the stability of GABAergic synapses. Mol. Cell. Neurosci. 36 484-500.
Yuk, J. S., Jung, S. H., Jung, J. W., Hong, D. G., Han, J. A., Kim, Y. M., and Ha, K. S. (2004). Analysis of protein interactions on protein arrays by a wavelength interrogation-based surface plasmon resonance biosensor. Proteomics 4, 3468-3476.

Yuzaki, M. (2010). Synapse formation and maintenance by $\mathrm{Clq}$ family proteins: a new class of secreted synapse organizers. Eur. J. Neurosci. 32, 191-197.

Zhang, C., Atasoy, D., Araç, D., Yang, X., Fucillo, M. V., Robison, A. J., Ko J., Brunger, A. T., and Südhof, T. C. (2010). Neurexins physically and functionally interact with GABAA receptors. Neuron 66, 403-416.

Ziff, E. B. (1997). Enlightening the postsynaptic density. Neuron 19, 1163 1174

Zita, M. M., Marchionni, I., Bottos, E., Righi, M., Del Sal, G., Cherubini, E., and Zacchi, P. (2007) Post-phosphorylation prolyl isomerisation of gephyrin represents a mechanism to modulate glycine receptors function. $E M B O \mathrm{~J} .26$, 1761-1771.

Zuber, B., Nikonenko, I., Klauser, P., Muller, D., and Dubochet, J. (2005). The mammalian central nervous synaptic cleft contains a high density of periodically organized complexes. Proc. Natl. Acad. Sci. U.S.A. 102, 19192-19197.

Conflict of Interest Statement: The authors declare that the research was conducted in the absence of any commercial or financial relationships that could be construed as a potential conflict of interest.

Received: 15 April 2011; paper pending published: 28 April 2011; accepted: 23 May 2011; published online: 06 June 2011.

Citation: Sassoè-Pognetto M, Frola $E$ Pregno G, Briatore F and Patrizi A (2011) Understanding the molecular diversity of GABAergic synapses. Front. Cell. Neurosci. 5:4. doi: 10.3389/fncel.2011.00004 Copyright $\odot 2011$ Sassoè-Pognetto, Frola, Pregno, Briatore and Patrizi. This is an open-access article subject to a nonexclusive license between the authors and Frontiers Media SA, which permits use, distribution and reproduction in other forums, provided the original authors and source are credited and other Frontiers conditions are complied with. 